absorption in the large intestine. It seems therefore that in these calves, as a minimum estimate, about 40-70 per cent of the magnesium escaping absorption in the small intestine was absorbed in the large intestine (about 25-40 per cent of the dietary magnesium).

In the older age groups a different situation existed. The magnesium/polyethylene glycol ratio in the fæces increased with age to such an extent as to indicate a decrease in overall magnesium utilization comparable to that shown previously by balance experiments ${ }^{3,4}$. Although net absorption in the small intestine may have fallen to some extent with age (this could be at least partly explained by there being a relatively greater amount of endogenous magnesium for the older and bigger calves) it appears that the factor mainly responsible was a decrease in the absorptive function of the large intestine. Exact interpretation is difficult since most of the results for the older calves were obtained on small samples from simple canulæ but it seems probable that these calves did not absorb any appreciable amount of magnesium in the large intestine.

These results also suggest that the increase in endogenous fæcal magnesium on a unit body weight basis previously observed as calves get older ${ }^{5}$ may be due to the failure of re-absorption in the large intestine.

I am greatly indebted to Dr. A. T. Cowie who inserted the canulæ for these experiments. I also wish to thank Mr. H. S. Hallett, Miss P. Lewis and Mrs. O. M. Campbell for technical assistance.

$$
\text { R. H. SмITH }
$$

National Institute for Research in Dairying, Shinfield, Reading, Berkshire.

$$
\text { June } 22 \text {. }
$$

1 Stewart, J., and Moodie, E. W., J. Comp. Path., 66, 10 (1956).

${ }^{2}$ Smith, R. H., J. A gric. Sci., 52, 72 (1959).

3 Smith, R. H., Biochem. J., 67, 472 (1957).

"Smith, R. H., Biochem. J., 70, 201 (1958).

Smith, R. H., Biochem. J., 71, 306 (1959).

Smith, R. H., Nature, 182, 260 (1958).

? Smith, R. H. (unpublished observations).

\section{An Attenuated Strain of Canine Distemper Virus in Tissue Culture}

CanINe distemper virus was cultivated in dog kidney tissue culture with a clear cytopathogenic effect ${ }^{1}$ and the 56 th passage of the virus was tested in ferrets. Each of four non-immune ferrets were inoculated intraperitoneally with $\mathrm{l} \mathrm{ml}$. of tissue culture fluid $\left(10^{5.5}\right.$ TCID 50$)$. Three non-immune ferrets were kept in the same laboratory as control animals and a further two in a neighbouring room in order to test for possible air-borne contamination from the inoculated animals. During an observation period of 25 days no animal showed any signs of disease. Blood was drawn from all the animals before the experiment and 17 days after inoculation. Tissue culture neutralization tests were performed with the sera, inactivated for half an hour at $56^{\circ} \mathrm{C}$., against $300 T C I D_{50}$ of canine distemper virus after incubation at room temperature for one hour. The 50 per cent neutralizing titre of sera from inoculated animals was more than $10^{-2}$ (final dilution of serum) on day 17, while neutralizing antibodies were not found, either in the pre-inoculation sera or in the sera from the control animals on day 17 .

On day 25 all the animals (from now on placed in the same laboratory) were challenged with Green's distemperoid virus (75 mgm. of freeze-dried ferret spleen). All the control animals developed clinically typical distemper after a uniform incubation time of 7 days, and were dead or killed with pronounced symptoms of distemper 11 days after challenge. The four animals inoculated with tissue culture virus showed no symptoms during an observation period of 3 weeks.

Apparently, during 56 passages in dog kidney tissue culture the virus becomes attenuated with a loss of pathogenicity for ferrets but it still retains a satisfactory antigenic capacity.

Tests in dogs are in progress and a complete report will be published elsewhere.

Department of Virus Research,

Gunnar RockBorn* Karolinska Institutet, Medical School, and the Medical Department of the Royal Veterinary College, Stockholm.

* Lowell M. Palmer Foundation Research Fellow. 1 Rockborn, G., Arch. Virusforsch., 8, 485 (1958)

\section{Physiological Activity in Extracts of Albizia Species}

InFORMATION was first received from Prof. C. Rendle-Short of the Department of Obstetrics and Gynæcology of this Medical School, that pregnant African women frequently take native medicines at or near term, even when in hospital, in an attempt to accelerate birth. It was thought likely that the excessively high incidence of uterine rupture occurring locally ${ }^{1}$, might be due in part to powerful uterine spasmogens in these medicines, and some of the plants were obtained from African herbalists and identified.

Cold aqueous extracts of the dried bark of Albizia gummifera (Gmel.) C. A. Smith and Albizia grandi. bracteata (Taub) and Albizia chinensis (Osbeck) Merrill were found in vitro to produce powerful contractions in strips from the gravid uteri of mice, rats, guinea-pigs, sheep, cows and humans. The mouse and rat uteri were less sensitive than those of the other animals, and non-gravid uteri were responsive but much less sensitive. Marked effects were produced by a concentration of the extracts in the isolated organ bath of the order of $100-500 \mu \mathrm{gm} . / \mathrm{ml}$., expressed as dry bark weight/bath volume.

The responses still occurred unchanged in the presence of sufficient atropine and antihistamines to abolish the responses to acetyl choline and histamine, and the extracts did not affect guinea-pig duodenum or ileum in vitro, nor did they affect the rectus muscle of the local toad, Bufo regularis (Vai).

For further study, inert residues were removed by preliminary extraction of the bark with neutral lowboiling hydrocarbons; extracts then obtained with aqueous lower alcohols were found to contain most of the active material.

A further inactive fraction was removed either by precipitation from aqueous solutions by basic lead acetate, or by a method devised by Drs. S. Wilkinson and H. T. Openshaw of the Wellcome Research Laboratories, Beckenham, England, involving dialysis and freeze-drying. The yield varied from 10 to 45 mgm./gm. of dry bark.

The activity was completely destroyed on mild acid hydrolysis, and prolonged boiling or prolonged standing, especially in sunlight, caused a steady decline of potency. The active material was not taken up by chloroform from neutral, acid or alkaline solution. The tentative conclusion that it was glycosidal and probably saponin in character, is supported by the work of Drs. Wilkinson and Openshaw. Saponins have been found in plants of the genus Albizia by other workers ${ }^{2}$. 